\title{
Secondary School Students' Attitudes Toward Teaching and Learning of Feminist Literature in Kenya
}

\author{
Dr. Simwa Solomon \\ Lecturer (adjunct), Department of Educational Studies, \\ University of Nairobi, Eldoret- Kitale \\ Dr. Anyonje Florence \\ Lecturer, Department of Languages, \\ Lugari Teachers' College
}

\begin{abstract}
Patriarchy in many societies has disadvantaged women in education, economic activities and leadership. The feminist movement is a major avenue through which women and other human rights activists seek to rectify this situation. However, due to opposition from those who would like to maintain the status quo, the goals of feminism are not always easy to achieve. This scenario is reflected in some works of literature studied in Kenyan secondary schools. This paper highlights students' attitudes towards teaching and learning of feminist literature in Lugari area of Kenya. Data were collected using a self-developed and structured questionnaire. Frequency counts and percentages reveal that feminist literature has minimal positive impact on students' attitudinal development in terms of gender equality. Also, most students prefer male to female teachers teaching them feminist literature due to weaknesses related to female teachers as well as patriarchal backgrounds of the students.
\end{abstract}

Keywords: feminism, feminist literature, attitudes towards feminist literature, gender equality, patriarchy

\section{INTRODUCTION}

Most societies are patriarchal meaning that power relations are skewed in favour of males. Feminism is a kind of politics aimed at correcting this situation (Weedon, 1987). It ordinarily exists in form of advocacy for gender equality. Feminist literature, therefore, refers to works of literature that feature feminism prominently. Salient features of this literature include powerful female characters who not only outshine males but also defy cultural norms detrimental to socio-economic development of women.

Importance of feminism cannot be overemphasised. Women form majority of citizens in many societies. In Kenya for instance, they account for over $50 \%$ of the population (UNO, 2017). It means such a country cannot expect to develop when majority of her citizens are disadvantaged in critical areas like education, employment and leadership. Studies have actually established a positive correlation between societies' levels of gender equality and development (Bwisa, 2003). It is no wonder the U.N.O advises nations to pay special attention to goal number five of the Sustainable Development Goals (SDGs) that seeks to foster gender equality (Antonio, 2017).

Continued inclusion of feminist literature in Kenyan secondary school English courses is hence very appropriate. This literature has the potential to contribute to the country's quest to attain SDGs and second world economy status by the year 2030 (locally referred to as "Vision 2030"). 
Indeed experts advise teachers to realize that study of feminist literature should besides developing language, promote gender equality (Kabaji, 2004, Mwangi, 2004). Some of the texts featured in the secondary English course include The River and the Source (Ogolla, M), Coming to Birth (Oludhe, M), The Whale Rider (Witi Ihimaera), and a number of short stories and plays.

However, teachers and students bring to school societal values that often impact negatively on education of girls (Abdullahi, 2007). It is likely that such values do interfere with proper study of feminist literature. This paper highlights attitudes of Form IV students in Kenya toward teaching and learning of feminist literature basing on selected texts. It is based on a study that sought to find out whether study of these texts has any positive impact on the students' attitudinal development in terms of gender equality. It further investigated whether students have any preference regarding who should teach them such literature (between male and female teachers), and if so, why.

\section{Feminist Literature in Kenyan Secondary School English Course (Selected Texts) The River and the Source}

A success story of a uniquely strong woman called Akoko and her lineage in a highly patriarchal Luo society. Throughout the story, women outshine men in family management and education. The men actually just fizzle out of women's lives thanks to sheer stupidity, laziness, diseases, war and choking. Obura, her firstborn son is the first one. He wanders to Tanganyika where he dies in World War II. After her husband's death, Akoko thrives as a widow ending up with the largest herd of cattle in Sakwa. Otieno, the lazy and jealous brother-in-law, grabs her wealth forcing her to trek to Kisumu to seek help from colonial administration. Later, her daughter (Nyabera) marries Okumu, a poor man. Akoko, in defiance of Luo cultural practice of demanding for dowry, donates some of her wealth to him. She opposes dowry again during the marriage of Awiti, her granddaughter.

The focus of the story then shifts to Awiti. The first girl to join a mission school at Gem yet she emerges top in final examination. She joins a teachers' college then marries an ex-soldier. But still in her family, children with Akoko's genes outshine the others. There is Veronica who, in a rare feat of female academic excellence, proceeds to study electrical engineering at the university. Another "Akoko" in the university is Wandia Mugo. She is the best in her medical class beating Aoro, her boyfriend. She is incidentally the daughter of a widow in central Kenya. Few years into their marriage, Wandia goes abroad to further her studies then returns to head the Pathology Department of the University of Nairobi. Her husband on the other hand is still having his first degree.

\section{Coming to Birth(Marjorie Oludhe)}

It is another story of a woman's transformation from poverty, illiteracy and oppressive culture to literacy and economic independence. Just like Akoko, she is too strong to be bogged down by Martin, her husband and other men rooted in patriarchy.

She is married off to Martin at the age of 16, virtually illiterate and poor. She miscarries several times and preservers the husband's physical abuse. In Marjorie's witty praise of Europeans, a black police officer arrests Paulina when she gets lost in Nairobi just for a white one to release her (it is during colonial times). Other women in Nairobi are also facing problems posed by their promiscuous and irresponsible men. There is Mrs M (a minister?) whose husband is a senior government official but has sexual relationships with underage girls. Rhoda's husband is never at home, an understatement for his promiscuous nature. 
Paulina then joins Home craft Training School in Kisumu and later works around the town. Away from the husband, she has an affair with Simon leading to pregnancy after which she tosses him out of her house. But then the son she delivers perishes in political fracas forcing her to return to Nairobi. That is how she starts working for Mrs. M as a house help. Her employer injects gender activism in her and they together fight for the release of Chelegat Mutai, the only female M.P., from prison. As she goes on with her life, Martin cohabits with several women but fails to get a child. He has no option but to re-join Paulina to survive. He arrives emaciated and haggard while she is brimming with health.

\section{Short Stories \\ Heaven and Earth}

Mme Lady poses as successful and happily married in church. The noble facade helps to conceal domestic violence in her life. She hates the Vicar who incidentally mirrors her violent husband. It is the reason why she deliberately comes to church late; shuffling and colourfully dressed to shift the congregation's attention from the Vicar to herself. To hit back, the Vicar has made the Biblical verse that advises women to humble and submit themselves to their husbands a "pet sermon". The "contest" between them rages on until the day she is beaten by the husband right outside the church. But Mme Lady says she cannot leave him for she relies on the husband for subsistence. He also paid a high dowry for her and hence her family may not accept her back. Other men in the story are also said to be non-religious and irresponsible.

\section{Solitude}

Women in this story are in prison physically and mentally. The society expects them to be meek and obedient or else they should be caned 30 times (a cultural decree). One of the prisoners is Boduur who has accepted the status quo due to religious and patriarchal socialization. She believes women are nearer Satan than men because of Eve in the Bible. They were also created from a crooked rib and so men's blows are meant to straighten them!

\section{Letter to my Sisters}

Dr. Dao is a young woman and the first female medic in her community. But the father has barred her from having any boyfriend, wearing trousers or staying in a house the government has offered. He considers such a lifestyle alien, immoral and a product of western education. The worst comes when he orders her to marry an Islamic teacher as a third wife. The teacher is much older and has a reputation of beating his wives and children. Dr. Dao is hence faced with a dilemma: Accepting means compromising her freedom; refusing will bring dishonour to her family (a cultural belief). She has, therefore, decided to commit suicide hoping that her death will jolt her community to re-think its treatment of girls and women. She is putting all the complaints she has in a letter she intends to leave behind for her sisters to read.

\section{STATEMENT OF THE PROBLEM}

For the last 15 years, there has been an increase in the study of feminist literature in Kenyan secondary school English course. For example, novels studied so far include The River and the Source (Margaret Ogolla) and Coming to Birth (Marjorie Oludhe). Feminist issues have also featured in a number of poems and short stories studied during the same period. However, pioneer feminist literary theorists such as Barbara (1997) have observed that feminist texts do not usually receive the attention they deserve in literary studies. Nevertheless, little attempt has been made to document attitudes of secondary school students in Kenya towards the teaching and learning of feminist issues in literature. This study investigated such attitudes 
among students in public secondary schools in Lugari, Kenya. The study specifically sought to answer the following questions:

1) Does the study of feminist literature promote positive attitudes towards gender equality among Kenyan secondary school students?

2) Do students in Kenyan secondary schools have any preferences regarding gender of teachers when it comes to teaching of feminist literature?

\section{Research Design}

\section{METHODOLOGY}

The study was a qualitative survey of students' attitudes towards teaching of feminist issues in literature.

\section{Population}

Target population was all Form IV students in public secondary schools in Lugari, Kenya.

\section{Sample and Sampling Techniques}

The study sample comprised 370 students selected through purposive and stratified random sampling.

\section{Research Instruments}

The main research instrument was a self-developed structured questionnaire. The questionnaire had two parts. Introductory part captured demographic data of respondents; part II had 14 Likert-type items and two others. Of the two, one was multiple choice type and another one open-ended. Responses for Likert-type items were organized into 2 points disagree (D) and agree (A). The questionnaire covered selected feminist issues related to cultural beliefs and practices featured in literature texts studied in secondary schools. Face validity of the questionnaire was ascertained by specialists from Department of Curriculum Instruction and Educational Media (CIEM), Moi University, Kenya.

\section{Procedure}

Participants were taken through a brief introduction on how to respond to the questionnaire and its importance. They were then requested to agree or disagree with items by way of checking appropriately. The researcher administered the questionnaire with the help of two research assistants.

\section{ANALYSIS}

Responses were analyzed basing on frequency counts then converted to percentages. 


\section{Table 1: Form IV Students' Attitudes Toward Teaching and Learning Feminist Literature} $(n=370)$

Coming to Birth

sex

I agree with Ahoya that when Martin beats up Paulina, it is a sign of love

I feel it is the duty of a wife like Paulina to carry all the luggage while walking with the husband

Because of childlessness, Martin is right to have an affair with Nancy while Paulina is wrong to have a relationship with Simon

From the novel, I think men are generally violent, unfaithful, and eat a lot in funerals

After preparing supper, Paulina is right not to start eating until her husband wakes up from his sleep

The River and the Source

I support the idea of arranging a marriage for girls the way Akoko is married off to Chief Owuor Kembo

Akoko is right to refuse to be inherited after the death of her husband

From the example of Awiti, Vera and Wandia Mugo, women are more hardworking and intelligent than men

I support Akoko's view that it is not necessary for a man to be asked to pay a lot of bride wealth during marriage

Looking at Akoko and Wandia Mugo's mother, women do not necessarily need men to succeed in life

Short stories

I agree with the Vicar in Heaven and Earth that women should submit to their husbands always

I agree with Mme Lady in Heaven and Earth that once a man has paid dowry, the wife should not leave him no matter the circumstances

I agree with Boduur in Solitude that women are nearer Satan than men because of Eve in the Bible

In Letter to my Sisters, I support Dao's father that unmarried girls should not wear trousers or live alone.
Agree \%

$66 \%$

$14 \%$

$83 \%$

$17 \%$

$58 \%$

$12 \%$

$31 \%$

$68 \%$

$48 \%$

$13 \%$

$18 \%$

$08 \%$

$77 \%$

$94 \%$

$23 \%$

$72 \%$

$84 \%$

$33 \%$

$21 \%$

$36 \%$

$76 \%$

$17 \%$

$53 \%$

$08 \%$

09\%

04\%

$03 \%$

$01 \%$

Between a male and female teacher, whom do you prefer teaching you stories dealing with women's lives such as The River and the Source and Coming to Birth? (Please check)

$$
\begin{aligned}
& \text { Female teacher } \mathbf{8 9}(\mathbf{2 4 \% )}) \\
& \text { Male teacher } \quad \mathbf{2 2 9}(\mathbf{6 2 \% )}) \\
& \text { Any teacher } \quad 52(14 \%)
\end{aligned}
$$

\section{RESULTS AND DISCUSSION}

\section{Does the study of feminist literature have any positive impact on students' attitudinal development in terms of gender equality?}

The above findings indicate that study of feminist literature tends to divide students into two camps. The boys generally show a lot of support for negative cultural practices and beliefs featured in literature books dowry and wife-beating. Girls on the other hand do not. This scenario is a reflection of what exists in patriarchal societies outside the schools. 
There were six issues out of the fourteen on which boys and girls harboured similar attitudes. These were wife inheritance, prospects of women succeeding in life without men; arrangement of marriages; girls wearing trousers and living alone; wives waiting for their husbands before having a meal, and the idea of women being more evil than men because of Eve in the Bible. They were opposed to them save for the second one.

\section{Between male and female teachers, do students have any preferences regarding who should teach them feminist literature?}

Majority of students $229(62 \%)$ prefer male to female teachers when it comes to the study of feminist literature. All reasons cited by students in response to the last item fell into three major strands of thinking. The first one was the feeling that male teachers encourage debate on issues raised by the books compared to female ones. Examples given include wife beating, wife inheritance, dowry and Female Genital Mutilation (F.G.M). Most of the students claimed that male teachers were more open and willing to answer their questions unlike females who usually felt pestered by the students.

The second view was that female teachers tended to be emotional while discussing issues like infidelity in marriage, childlessness and wife beating/domestic violence. Students, therefore, feared to engage the teachers in further debate. Analysis of these issues was hastily done leaving students yearning for more information.

Yet another problem they cited among female teachers was rigidity. Students felt that male teachers usually accommodated their views while female ones were rigid and often imposed their standpoints on them. That situation made students feel left out in the teaching and learning process.

\section{CONCLUSION AND RECOMMENDATIONS}

Study of feminist literature has minimal positive impact on students' attitudinal development in terms of gender equality, especially the boys. It should, however, be encouraged because it elicits great debate among students as seen through their teacher preferences. As Lazar (1993) observes, teachers need to realise that teaching and learning of literature should generate debate and even controversy in the classroom. It is healthy and a good opportunity for them to shape students' attitudes towards aspects of life such as gender equality.

Education has a duty to develop modern and responsible citizens. It is necessary for the Ministry of Education in conjunction with Ministry of Culture and Social Services to mount workshops and seminars for teachers of English to sensitize them on how to handle feminist literature. For example, complaints raised against female teachers could be addressed that way. In addition, more research needs to be conducted on why male teachers are praised by the students yet the same students demonstrate minimal positive attitudinal development in terms of gender equality. Methods such as interviews with the teachers and group discussions with students may provide more insight into this topic.

\section{References}

Abdullahi, E. (2007). Gender Sensitivity in Classroom Teaching and Learning. In The Educator, Journal of the School of Education, Moi University, Vol.1 (2), pp. 243-254.

Barbara, L. (1997). Femininity and Shame. New York: Maryland University Press.

Bwisa, H. (2003, April 13). Empower Women for Quicker Economic Recovery. Nairobi: Sunday Nation, p.5.

Antonio, G. (2017, March 8). Why Propping up Women is a Worthy Goal. Nairobi: Daily Nation, p.15 
Kabaji, E. (2004, March 24). An Insight into the Polemics of Gender. Nairobi: Sunday Nation p.12.

Lazar, G. (1993). Literature and Language Teaching. Cambridge: Cambridge University Press.

Macgoye, O. (2005). Coming to Birth. Nairobi: East African Educational Publishers.

Mwangi, E. (2004, March 21). Hope Grows as Women's Letters Claim Bigger Space. Nairobi Sunday Nation p. 12.

Ogola, M. (1994). The River and the Source. Nairobi: Focus Books.

United Nations Organization (2017). Kenya Population Data. Retrieved from

http://data.un.org/Countryprofile.aspx?crName=kenya, on 14 Mar. 2017.

Weedon, C. (1987). Feminist Practice and Theory. New York: Blackwell.

Coming to Birth

APPENDIX 1: STUDENTS' QUESTIONNAIRE

I agree with Ahoya that when Martin beats up Paulina, it is a sign of love

I feel it is the duty of a wife like Paulina to carry all the luggage while walking with the husband

Because of childlessness, Martin is right to have an affair with Nancy while Paulina is wrong to have a relationship with Simon

From the novel, I think men are generally violent, unfaithful, and eat a lot in funerals

After preparing supper, Paulina is right not to start eating until her husband wakes up from sleep

The River and the Source

I support the idea of arranging a marriage for girls the way Akoko is married off to Chief Owuor Kembo

Akoko is right to refuse to be inherited after the death of her husband

From the example of Awiti, Vera and Wandia Mugo, women are more hardworking and intelligent than men

I support Akoko's view that it is not necessary for a man to be asked to pay a lot of bride wealth during marriage

Looking at Akoko and Wandia Mugo's mother, women do not need men to succeed in life

Short stories

I agree with the Vicar in Heaven and Earth that women should submit to their husbands always

I agree with Mme Lady in Heaven and Earth that once a man has paid dowry, the wife should not leave him no matter the circumstances

I agree with Boduur in Solitude that women are nearer Satan than men because of Eve

I support Dao's father that unmarried women should not wear trousers or live alone in Letter to my Sisters
M

$\mathrm{F}$ $\mathrm{M}$ $\mathrm{F}$ $\mathrm{M}$ $\mathrm{F}$ $\mathrm{M}$ $\mathrm{F}$ M F 
Solomon, S., \& Florence, A. (2017). Secondary School Students' Attitudes Toward Teaching and Learning of Feminist Literature in Kenya. Advances in Social Sciences Research Journal, 4(9) 21-28.

Between a male and female teacher, whom would you prefer to teach you books dealing with women's lives like The River and the Source and Coming to Birth? (Please check)

Female teachers

Male teachers

Any teacher

Give any reason or reasons for your answer 